\title{
Household Consumption Process at the Different Stages of Social Development on the Way to the Digital Economy
}

\author{
Rakhmatullina D.K. ${ }^{1, *}$ Guzelbaeva G.T. ${ }^{1}$ Novikov D.S. ${ }^{2}$ \\ ${ }^{1}$ Kazan Federal University, Kazan, 420008, Russian Federation \\ ${ }^{2}$ Kazan State University of Architecture and Engineering, 420043, Russian Federation \\ *Corresponding author. Email: na_nulya_@list.ru
}

\begin{abstract}
In modern conditions of digitalization, significant transformations are occurring in all spheres of the social life, including the features of economic relations. The digital economy is the latest system that defines qualitatively new processes of consumption and production. Their traditional understanding and essence is changing due to the special properties of digital goods as the center of reproduction in the digital economy.

To formulate an modern model of consumer behavior, it is necessary to identify the main directions of changes. It is important to analyze the characteristics of consumption at different stages of the society development from the primitive of the ancient times to the digital economy of the future, which are characterized by different types of economic systems.

The article provides a detailed analysis and comparative characteristics of the process of personal consumption in conditions of different types of economic systems, including the digital economy of the future. It is concluded that it is necessary to modernize the current generally accepted theoretical approach to personal consumption in order to universalize it for any economic conditions and take into account the many factors that affect it.
\end{abstract}

Keywords: consumption, needs, preferences, economic systems, satisfaction, consumer choice, digital economy

\section{INTRODUCTION}

Economic theory considers consumption as the central process of economy. Everything in economy is intended for consumption. Personal consumption is associated with the extraction of useful properties of goods in order to meet human needs. Needs determine consumer preferences and choices.

In the conditions of digitalization, significant changes occur in the essential semantic and organizational content of the reproduction process at each stage, including the final - consumption. The key object of transformation is an economic good that takes a digital form with its distinctive properties that contradict the usual concept of rare goods. There is an acute problem of discrepancy between the traditional theory of consumer demand and choice in the digital economy and the need to adapt it to new conditions is realized.

For a detailed study of the process of personal consumption in the modern conditions of the digital economy we will consider how the needs of an individual are formed at different stages of economic development of society, who the consumer is, how he makes his choice and what motivators rule him in his economic activities.

\section{RESEARCH METHODS}

Using methods of analysis, scientific abstraction, induction and deduction, we consider the conditions under which the formation and implementation of the consumption process occurs at different stages of the economic development with inherent types of economic systems, and highlight the direct features of the consumption relations system: needs, ways and opportunities to satisfy them, ways to make decisions about consumption and its determining factors.

\section{RESULTS}

Modern traditional economic theory identifies four types of economic systems[1]:

* traditional economy - economic activity is based on inherited traditions, collective experience of past generations, and customs;

* command-administrative or centrally managed economy - the activity of individual structural units of social production in it is aimed at achieving local goals of a single General plan, which is expressed in the policy tasks 
brought by planning authorities (the state) to the enterprises;

* market economy - activity is based on private interests, the distribution of resources occurs spontaneously, based on the mechanism of supply and demand, the free play of market forces;

* mixed economy - an economy that combines private, corporate, and public interests, with market-based or centralized management prevailing.

Table 1 Features of the economic systems in the pure and simple forms from the point of view of the individual consumer demand formation

\begin{tabular}{|c|c|c|c|}
\hline $\begin{array}{l}\text { Main } \\
\text { characteris } \\
\text { tic }\end{array}$ & Traditional economy & Centrally planned economy & Market economy \\
\hline $\begin{array}{l}\text { Form of ownership of the } \\
\text { conditions of production } \\
\text { (resources) }\end{array}$ & Community (collective). & Public. & Private. \\
\hline Purpose of the owner entity & Maintenance of life. & $\begin{array}{l}\text { Improving the welfare of } \\
\text { society and the country as a } \\
\text { whole. }\end{array}$ & Improving the welfare of an individual. \\
\hline $\begin{array}{l}\text { Level of development of social } \\
\text { production }\end{array}$ & Low. & $\begin{array}{l}\text { Mid-range. The planned system } \\
\text { slows down scientific and } \\
\text { technical progress, there is no } \\
\text { incentive to develop, search for } \\
\text { new technologies }\end{array}$ & $\begin{array}{l}\text { Increasing. The competitive struggle inherent } \\
\text { in a market economy leads to the search for } \\
\text { new technologies that improve the individual's } \\
\text { well -being. The gap in welfare levels between } \\
\text { the winner of a competitive race and the loser } \\
\text { does not allow their further effective } \\
\text { interaction, which leads to failures in the } \\
\text { reproduction process and does not ensure a } \\
\text { high level of development of social production. }\end{array}$ \\
\hline The growth rate of needs & $\begin{array}{l}\text { Low. The growth of needs } \\
\text { is hindered by the low } \\
\text { level of development of the } \\
\text { entire society, the main } \\
\text { goal of which is to adapt to } \\
\text { the surrounding conditions, } \\
\text { survival. }\end{array}$ & $\begin{array}{l}\text { Restrained by the state. The } \\
\text { planned economy does not take } \\
\text { into account the constantly } \\
\text { growing nature of needs, and if } \\
\text { some needs are not met, then } \\
\text { new ones will not appear. }\end{array}$ & $\begin{array}{l}\text { High. Any new need is reflected in the } \\
\text { production process and can be satisfy, this } \\
\text { creates conditions for their constant growth. }\end{array}$ \\
\hline $\begin{array}{ll}\text { The clear-formedness } & \text { of } \\
\text { needs } & \end{array}$ & $\begin{array}{l}\text { Clear-formed. They are } \\
\text { dictated to a greater extent } \\
\text { by the nature and human } \\
\text { physiology. }\end{array}$ & $\begin{array}{l}\text { Clear-formed. Dictated by the } \\
\text { state. }\end{array}$ & $\begin{array}{l}\text { Clear-formed. A rational consumer knows } \\
\text { exactly what he needs and in what quantities. } \\
\text { The stage of development of the goods } \\
\text { production defines the limits in its quality } \\
\text { (standardized) and quantitative expression. }\end{array}$ \\
\hline Consumer satisfaction & $\begin{array}{l}\text { Low, but as the transition } \\
\text { from the appropriating } \\
\text { economy to the producing } \\
\text { one increases within the } \\
\text { framework of the formed } \\
\text { needs. }\end{array}$ & $\begin{array}{l}\text { Low, but most often consumers } \\
\text { do not realize this. Their } \\
\text { peculiarity is the corporate } \\
\text { spirit, the implementation of } \\
\text { the plan (the main task set by } \\
\text { the state) - the peak of } \\
\text { satisfaction. }\end{array}$ & $\begin{array}{l}\text { Different, depending on the size of the } \\
\text { consumer's disposable income. }\end{array}$ \\
\hline Motivational activity & $\begin{array}{l}\text { High objective, dictated by } \\
\text { the fear of starvation. }\end{array}$ & $\begin{array}{l}\text { High objective, dictated by the } \\
\text { fear of punishment and } \\
\text { starvation. }\end{array}$ & $\begin{array}{l}\text { High objective, dictated by the fear of loss of } \\
\text { the income and starvation. }\end{array}$ \\
\hline Examples & $\begin{array}{l}\text { The primitive communal } \\
\text { system. }\end{array}$ & USSR. & $\begin{array}{l}\text { Capitalist countries in the era of perfect } \\
\text { competition. }\end{array}$ \\
\hline
\end{tabular}

In the context of modern transformations it is necessary to distinguish the fifth type of economic system:

* digital economy, which characterizes a qualitatively new way of organizing interactions between economic objects in the reproduction of goods. 
The first three systems in their pure form today we can only find in textbooks, history has shown their independent failure. However, each of them reflects certain stages in the development of economic relations in the world economy. Today, the most common system of economics is its mixed type, which includes features of two or more systems of a pure type. Therefore, the analysis of the features of economic relations in the economy under these types of conditions is also necessary. Throughout the history of economic development, there has been an epoch-making shift in society's commitment to a particular school of economic thought, which in one way or another represented a theoretical model of consumption. Each approach to consumption theory reflects the characteristics of the economic system in which the economist who proposed it lived and worked.

Table 1 shows the features of the economic systems in their pure and simple forms from the point of view of consumer demand formation.

None of the economic systems discussed above is characterized by effective relations between economic entities with the best results of their activities. Traditional economic system provided to develop industrial relations and production technologies. It occurred in the context of its low productivity and the desire to improve the economic situation by using human intellectual abilities to search for the new technologies. Scientific and technical revolutions led to the formation of qualitatively new relations of production and consumption in a market capitalist economy. This economic system proved to be a "failure" and caused large-scale negative social and economic consequences (the "great depression"). In contrast to the inhumane rigid market economy with the exploitation of some people by others, the theory of the Communist way of life was proposed, which is based on a centrally planned or command-administrative economic system. Countries that have chosen this path of development came to a stagnant economic situation and decline due to the lack of a competitive mechanism for racing and improving reproduction processes.

In this regard, the most common in the modern world is a mixed economic system that reflects the conditions and features of economic relationships between subjects in the conditions of industrial and post-industrial production technologies. But digitalization, which is gaining momentum and affecting more and more aspects of society, leads to the formation of a new system of economic relations and the need to allocate a new model of the digital economy.

Table 2 shows the features of consumer demand formation in the conditions of the modern mixed-type economic system and the digital economy of the future with a large share of the digital goods production.

Household economic behavior is formed by the influence of a complex system of interrelated factors, impacted by macroeconomic situation and world conjuncture. As the economic system of each country develops historically, the trend in households' economic behavior reflects the specific of development, the national peculiarities of formation and functioning of a country in close connection with its integration into the world economy. [8] The macroeconomic factors affect household consumption, such as the indicators related to the functioning of the economy as a whole and conducted public policy, for example. [9] Consumption is the central process in household economic behavior, that's why all of the wide specter of different significant factors of its forming and realization are also the factors of consumption process.

\section{DISCUSSION}

Consumption is the final stage of the reproduction cycle. Its character reflects the features of economic relations that arise in the existing system between agents. History shows that each stage of development of the world economy, characterized by certain methods and technologies of production, differs and corresponding features of the formation and implementation of consumer demand.

The fourth industrial revolution is leading to a digital transformation of production processes in all industries, as digital technological advances - 3D printing, large databases, human-robot cooperation - have a radical impact on the micro-level of organization and management of production. By providing real-time information about demand, production capacity, performance and product quality, industry 4.0 will allow you to make decisions that significantly improve process efficiency in everything from pricing to production planning. [10]

The features of forming relations between economic agents are also determined by the features of digital goods themselves. They have a fundamental difference from material goods - with access to the ICT infrastructure, both the creation of a copy and the delivery of digital goods to the consumer practically do not create economic costs. Both of these processes - copying (production of another copy of the same type of product) and delivery (moving in space) of material goods - in most cases generate the bulk of the costs borne by their consumers. Thus, the marginal cost (the extra products cost) of production and delivery of a second and subsequent copy of the digital good to the consumer is close to zero. This unique property of the digital goods creates the conditions necessary to fundamental changes in the production and economic relations of the society. [2]

Radical changes are observed in the process of forming and making decisions about consumption in the conditions of digitalization. The nature of the organization of the process of purchasing and extracting utility is changing.

All of these transformations should be taken into account and reflected in the modern theory of Economics. 
Table 2 Features of the economic systems in the mixed and digital forms from the point of view of the individual consumer demand formation

\begin{tabular}{|c|c|c|}
\hline Main & Mixed economy & Digital economy \\
\hline $\begin{array}{l}\text { Form of the conditions of } \\
\text { production } \\
\text { ownership }\end{array}$ & Private or public. & $\begin{array}{l}\text { Private or public, while the cost of producing digital goods will } \\
\text { eventually approach zero and this fact will reduce the value of } \\
\text { the production resources ownership. [2] }\end{array}$ \\
\hline Purpose of the owner entity & $\begin{array}{l}\text { Improving the welfare of society and its } \\
\text { members. }\end{array}$ & $\begin{array}{l}\text { Improving the well-being of society and its members in a } \\
\text { globally competitive digital economy. }\end{array}$ \\
\hline $\begin{array}{l}\text { Level of the social production } \\
\text { development }\end{array}$ & $\begin{array}{l}\text { High, achieved by ensuring and supporting } \\
\text { continuous reproduction by smoothing and } \\
\text { overcoming market "failures". }\end{array}$ & $\begin{array}{l}\text { High speed.[3] Due to a significant reduction of the apparent } \\
\text { costs in the process of organizing and implementing each of the } \\
\text { stages of reproduction by the usage of the latest high-speed } \\
\text { technologies. }\end{array}$ \\
\hline The clear-formedness of needs & $\begin{array}{l}\text { Needs are not clear-formed due to their } \\
\text { constant growth and qualitative changes. } \\
\text { Needs are expanded by the competitive supply } \\
\text { of new technological products that satisfy } \\
\text { needs have not been yet recognized and } \\
\text { accepted by consuming households. The needs } \\
\text { structure of a person can vary during different } \\
\text { periods of his life. [5] }\end{array}$ & $\begin{array}{l}\text { They are clear-formed in the short term and can be transformed } \\
\text { by external factors in the long term. The consumer is picky, not } \\
\text { "omnivorous". Knows what things and in what quality he needs } \\
\text { today and now. More importance is given to the impression of } \\
\text { consumption than to the direct consumption. [4] }\end{array}$ \\
\hline Consumer satisfaction & $\begin{array}{l}\text { Different, depending on many factors other } \\
\text { than the consumer's income.[6] Reaching the } \\
\text { maximum level of satisfaction is unlikely, } \\
\text { since new needs are constantly imposed by the } \\
\text { market, reducing the total satisfaction of pre- } \\
\text { existing needs. }\end{array}$ & $\begin{array}{l}\text { Different, depending on many factors other than the consumer's } \\
\text { income. An important role is played by access to the global } \\
\text { network and the developed accompanying infrastructure of the } \\
\text { market. }\end{array}$ \\
\hline Motivational activity & $\begin{array}{l}\text { Mid-range and subjective, dictated by the fear } \\
\text { of a decline of the quality of living and the } \\
\text { provision of goods. }\end{array}$ & $\begin{array}{l}\text { Low and subjective. To be satisfied and happy and recognized } \\
\text { by society in this [7], leads to a transition from demonstrative } \\
\text { personal consumption of material goods and services (now they } \\
\text { are publicly available, demonetized due to the digitalization of } \\
\text { production) to demonstrative production of publicly available } \\
\text { digital goods. }\end{array}$ \\
\hline Examples & Modern countries & Modern countries at the end of the fourth industrial revolution. \\
\hline
\end{tabular}

\section{CONCLUSION}

The research work showed that personal consumption is a complex, multi-stage process that differs in its manifestations in each economic condition. Theoretical justification and modeling of this process is necessary for forecasting and evaluating the real situation of consumption and identifying its existing trends that will help in the objective forecasting of the development of reproduction social relations.

The digitalization of the economy transforms the entire system of reproduction relations. There is an urgent need to revise the traditional theory that explains the patterns of consumer decisions. Adjustments should be made or a completely new alternative should be found, which meets the requirements and takes into account the conditions of any economic systems formed in the society, in the past, now and in the future. New theory should take into account the features of consumer demand formation in the conditions of each corresponding economic system. 
[9] J., Varlamova, N., Larionova, Macroeconomic and

\section{ACKNOWLEDGMENT}

The reported study was funded by RFBR, project number 20-010-00663 "Evolution of the individual and household's economic behavior model in the digital transformation".

\section{REFERENCES}

[1] N. V., Kapitonova, E. P., Albitova, P. A. Kisloshchaev, Formation of economic culture of economic entities by types of economic systems, Bulletin of the TRANS-Baikal state University, vol. 23, no. 12,2017 , pp. 121-133.

[2] S.V., Makrushin, Digital economy: transformation of technologies into a new economic order, Property relations in the Russian Federation. 2018, Vol.2 (197), pp. 10-18. DOI: https://doi.org/10.24411/2072-40982018-12001

[3] N. R., Saenko, Speed: disaster or good? (Review of the book by D. Weissman "Time is running out: accelerating life under digital capitalism"), Service + . 2019, Vol.3, pp. 93-95

[4] A.V., Markeeva, O.V., Gavrilenko, Transformation of consumer practices: new scenarios of consumer behavior and ways to organize trade spaces, Bulletin of the Moscow University. Series 18. Sociology and political science, 2017, Vol.2, pp. 92-115

[5] E., Fakhrutdinova, A., Vasiljev, Needs and the quality of life: aspects of the interaction, Economic science 10, 2009, pp. 90-93

[6] D.K., Rakhmatullina, E.R., Akhmetshina, A.M., Safiullina, Factor analysis of personal consumption in a modern welfare economy / D.K. Rakhmatullina, E.R. Akhmetshina, A.M. Safiullina // Journal of Physics: Conference Series, 2018, Vol.1141, Is.1, Art. №012014. DOI: https://doi.org/012014. 10.1088/1742$6596 / 1141 / 1 / 012014$

[7] M.Yu., Ya.A., Pogudaeva Semenova-Slabkovich, Features of consumer behavior in the conditions of information economy, Economic journal, Vol.28, 2012, pp. $96-104$

[8] N., Larionova, J., Varlamova, G., Singatullina, The Trends on Household Economic Behavior in Emerging Countries of Europe, Emerging markets queries in finance and business (EMQ 2013), Volume 15, pp. 421429. DOI: https://doi.org/10.1016/S22125671(14)00472-9 demographic determinants of household expenditures in OECD countries, International Conference On Applied Economics (Icoae) 2015, Volume 24, pp. 727-733. DOI: https://doi.org/10.1016/S2212-5671(15)00686-3

[10] K.A., Belokrylov, Prospects for digitalization of reproduction in the public sector, Russia: trends and prospects for development, 2018, Vol.13-1, pp. 243-247 